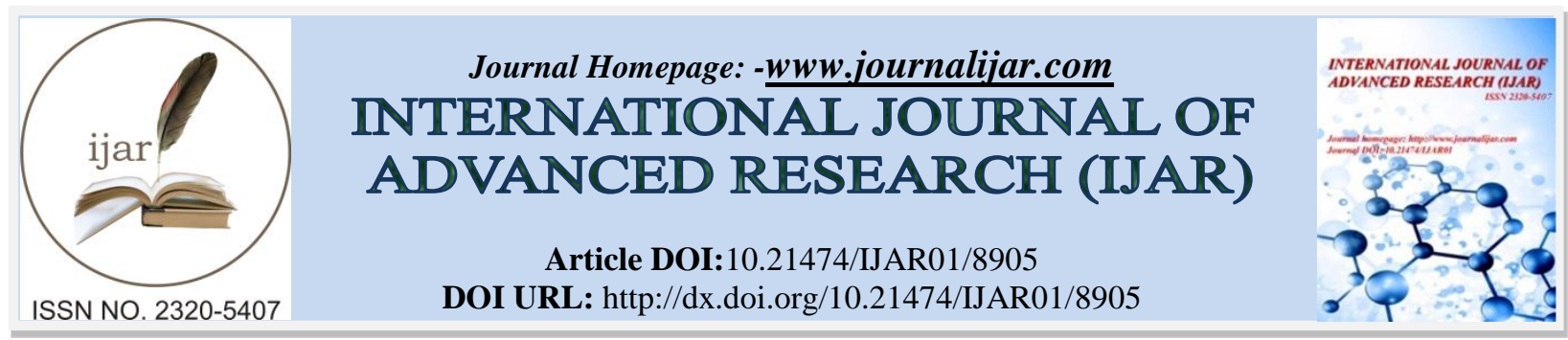

RESEARCH ARTICLE

\title{
CRITICAL ANALYSIS ON DOSHIK VARIATIONS IN RAJO NIVRUTTI W.S.R TO MENOPAUSE.
}

\section{Vibha.S ${ }^{1}$, Tahseen Ahmed.M ${ }^{1}$, Rashmi.B.M ${ }^{2}$, Nagesh.H.D ${ }^{3}$ and Janaki.Y.S ${ }^{4}$}

1. PG Scholars, Dept. of Roga Nidana \& Vikruthi Vijnana.

2. Assistant Professor, Dept. of Roga Nidana \& Vikruthi Vijnana.

3. Associate Professor, Dept. of Roga Nidana \& Vikruthi Vijnana.

4. Professor, Dept. of Roga Nidana \& Vikruthi Vijnana, Government Ayurvedic Medical College, Bengaluru.

\section{Manuscript Info}

\section{Manuscript History}

Received: 12 February 2019

Final Accepted: 14 March 2019

Published: April 2019

Key words:-

Kshetra, Jara, Pakva shareera, Menopause.

\section{Abstract}

The genesis of human life is housed in the body of female, with the very apt aphorism to 'Kshetra', mentioned in the annals of Ayurvedic literature. Though the kshetra loses its fertility or the ability to bear further, nonetheless it has to be cared for as it becomes vulnerable. The pantheons of Ayurveda have the consensus that the fertile period in a woman's life time is between 12 to 50 years, beyond which there is Jara(senility) due to Pakva shareera (ripening or degradation of the body).

Menopause is the period during which the menstrual cycle usually becomes irregular and subsequently ceases, ovulation fails to occur and the female sex hormones diminish to almost none. It demands the woman to readjust her life which was previously stimulated by hormones to one devoid of them. The life after menopause is marked by a series of tumultuous physiological changes including extreme flushing of the skin, irritability, fatigue, anxiety, occasional various psychotic states, decreased strength and calcification of bones throughout the body.

The incidence of menopause in Indian women is 40 to 50 years, with recent alarming reports of premature menopause, before 40 years.

The present work aims to understand the pathophysiology of menopause in Ayurvedic classics in understanding and improving the quality of life after menopause.

Copy Right, IJAR, 2019,. All rights reserved.

\section{Introduction:-}

Ayurveda, the science of life gives paramount importance to the preservation and maintenance of health in healthy individuals and restoration of healthy status in the ailing by curing the diseases. It also considers the old age or Jara avastha as a disease, albeit a Svabhavika, meaning that which cannot be forgone. But all the same, ageing should not aggrieve an individual to the extent that it hampers the quality of life and even precipitates death. Geriatric population is currently about $10 \%$ of world population ${ }^{1}$ and elderly women have greater functional limitations than men of the same age group. Menopause is a resultant of the physiological burnout in the females. Management of menopause comes under gerontology, which deals with the study of physical and psychological

Corresponding Author:-Vibha.S, Tahseen Ahmed.M

Address:-PG Scholars, Dept. of Roga Nidana, Government Ayurvedic Medical College, Bengaluru, Karnataka, India. 
changes incidental to old age. The present study aims to view menopause as per Ayurvedic classics along with measures to improve the quality of post-menopausal life.

Aims and objectives:

To understand and review menopause as per Ayurvedic classics.

\section{Material and methods:-}

The current study is a result of studying and drawing references from the Brihattrayees or the Greater Triad of Ayurveda, Laghutrayees and the contemporary books on gynaecology and physiology.

\section{Observation:}

Average Age of Menopause $=\mathbf{5 0}$ years

Artava Pravrutti-Nivrutti Kala:

The first appearance of menses is at the age of 12 years and its cessation is around the age of 50 years, due to JaraPakva shareera. This cessation of menses is due to the gradual and progressive deterioration of the dehadhatus. (Su. Sha.3/11)

\section{Terminologies Used for a woman in menopausal phase:}

1. Adhirudha $\rightarrow 50$ years as per Bhavamishra

2. Vruddha $\rightarrow>50$ years as per Bhavamishra

3. Pragalbha $\rightarrow 41$ years as per Haritha.

Every female life has to go through a permanent and irreversible phase of the end of reproduction called menopause. Menopause means the stopping or pausing of menstruation or the monthly sexual cycle in a female. It is defined as the permanent cessation of menstruation at the end of reproductive life due to loss of ovarian follicular activity. It is the point of time when last and final menstruation occurs. ${ }^{2}$

The average age of menstruation in Indian women is 50 years, with a range of 40-55 years. The duration of 10-15 years before and after menopause are called pre-menopause and post-menopause periods. They are together called 'climacteric periods'. In the pre-menstrual climacteric period there is gradual decline in the amount of bleeding, irregularity in the monthly menstrual cycles. This is followed by the perimenopausal period, characterized by various impactful and mostly bothersome psychosomatic changes which progresses into menopausal period in which there is complete cessation of the monthly menstrual cycles accompanied by permanent changes in not just the reproductive, but most other systems in females.

Throughout a woman's reproductive life, about 400 of the primordial follicles grow into mature follicles and ovulate, and hundreds of thousands of ova degenerate. At about age 45 years, only a few primordial follicles remain to be stimulated by FSH and LH, and the production of oestrogen by the ovaries decreases as the number of primordial follicles approaches zero, when oestrogen production falls below a critical value, the oestrogen can no longer inhibit the production of the gonadotropins FSH and LH. ${ }^{3}$ This indicates the disturbance in the hypothalamopituitary-ovarian axis.

Menopause forces a woman to readjust her life from one that has been physiologically stimulated by estrogen and progesterone production to one that is devoid of these hormones. This leads to occurrence of marked physiological and psychological changes like:

1. extreme flushing of the skin

2. irritability

3. fatigue

4. anxiety

5. occasional various psychotic states

6. decreased strength and calcification of bones throughout the body 
The ailing sequela in menopause includes:

Vasomotor Symptoms: Hot Flush-

Sudden feeling of heat followed by profuse sweating. Low oestrogen and raised LH $\rightarrow$ affect thermoregulatory center in association with GnRH center in hypothalamus.

\section{Urogenital atrophy:}

Oestrogen deficiency produces atrophic epithelial changes in urethra, bladder, vagina and the pelvic floor muscles. Minimal trauma may cause vaginal bleeding along with dyspareunia, vaginal infections, dryness, pruritis and leucorrhoea.

\section{Osteoporosis \& fracture:}

Decline in collagenous bone matrix resulting in osteoporotic changes like: bone mass loss and micro-architectural deterioration of bone tissue. Morbidity and mortality in elderly women following fracture is high.

\section{Cardiovascular \& Cerebrovascular Effects:}

LDL oxidation, foam cell formation $\rightarrow$ vascular endothelial injury: cell death \& smooth muscle proliferation $\rightarrow$ vascular atherosclerotic changes, vasoconstriction \& thrombus formation $\rightarrow$ Risks of IHD, CAD \& strokes.

\section{Dementia \& cognitive decline:}

decreased protective function of oestrogen on cns leads to dementia and alzhiemer's disease.

\section{Skin \& hair:}

Thinning, loss of elasticity and wrinkling of the skin as the maximum no. of oestrogen receptors are present in the facial skin, slight balding, loss of pubic and axillary hair due to reduced oestrogen but normal testosterone levels.

\section{Psychological changes:}

Anxiety, headache, insomnia, irritability and depression, mood swings and inability to concentrate are the common presenting features.

\section{Sexual dysfunction:}

Decreased desire due to oestrogen deficiency.

In the Ayurvedic literature menopause can be definitely identified as Rajo Nivrutti Kala. This is the time period during which there is stoppage of Raja or Artava. It is said to occur at Panchashat Varsha, meaning 50 years. ${ }^{4,5}$ The causes for this Rajo Nivrutti is said to be Jara and Aparicheeyamana Shareera Dhatu, which means ageing brought about by deteriorating bodily tissues. This view is supported by Acharya Sushrutha and Acharya Vagbhata.

In addition, Acharya Sharngadhara elucidates the loss of certain psychosomatic faculties of the body at the completion of successive decades of life. In this regard he describes that there is loss of Medha and Tvak by the end of $4^{\text {th }}$ and $5^{\text {th }}$ decades ${ }^{6}$. This can be correlated to various psychotic states like anxiety, restlessness, short-temper, depression, diminished concentration and changes in skin like loss of elasticity, suppleness and wrinkling.

\begin{tabular}{|c|c|c|}
\hline & & \\
\hline COMPLAINTS & DOSHA ANALYSIS & GUNA ANALYSIS \\
\hline 1. Atisveda & PITTA & USHNA, SARA \\
\hline 2. Yoni Shula & VATA & CHALA \\
\hline 3. Yoni Kandu & KAPHA & $\begin{array}{l}\text { SNIGDHA, PICCHILA, KLEDA, } \\
\text { LIPTATA }\end{array}$ \\
\hline 4. Yoni Shushkata & VATHA & RUKSHA, KHARA \\
\hline 5. Shvetha Pradara & VATHA-KAPHA & CHALA, SANDRA \\
\hline 6. Sandhi Shoola & $\begin{array}{l}\text { VATHA VRUDDHI, KAPHA } \\
\text { KSHAYA }\end{array}$ & RUKSHA, KHARA \\
\hline 7. Bhagna & VATHA & RUKSHA, KHARA \\
\hline 8. Chittodvega & VATHA & CHALA, SUKSHMA \\
\hline 9. Atikrodha & PITTA & TIKSHNA \\
\hline
\end{tabular}




\section{Discussion:-}

Due importance has to be given to the management of menopausal syndrome as this is a leading issue and ever encountered until the existence of human race!

Diseases in the geriatric age group are characterized by:

1. Involvement of multiple pathologic processes in multiple organ systems

2. Presentation at an earlier stage of disease

3. Rapid deterioration if unattended to

4. Greater frequency of complications

5. Breakdown of personal, family, social, economic and environmental situations.

\section{Status of manas in menopause:}

It is seen that that the personality of the individual, in response to various conditions and diseases depends on the sub conscious mind. Charka in Shareera 4 says that the personality or psychological make-up of mind has effect on the body and vice versa ${ }^{7}$. This phenomenon is in healthy and diseased state. In the Samhita it is described that Shareera Doshas (Vata, Pitta and Kapha) affect Mano Doshas (Rajas and Tamas) and vice versa, i.e. if the state of equilibrium of the Shareera Dosha are disturbed Manasa Doshas are also vitiated and vice versa. In the description of the function of the Shareera Dosha certain Manasa Bhavas (mental function) are also done by them like, Vata is responsible for Utsaha, Niyanta Praneta cha manasah, Indriyartha grahana, Manas Gati, etc. Pitta in healthy state performs the functions of buddhi, medha etc. Whilst Kapha in its healthy state performs the function like Dhruti, Smruti etc. while Rajo Guna is a motivator of all the functions and it is expressed by activities of the Dosha; Tamo Guna is important for sleep and in this way it affects the activities of the body.

These interactions between Shareerika and Manasika Doshas are exhibited through features like: irritability, feelings of sadness, lack of motivation, anxiety, aggressiveness, difficulty in concentrating, fatigue, panic attacks and mood changes. Thus, menopause proves as an emotional roller-coaster in a woman's life.

\section{Diagnostic guidelines of menopause:}

- Cessation of menstruation for consecutive 12 months during climacteric period.

- Appearance of menopausal symptoms.

- Vaginal etiology-showing maturation index of at least 10/85/5-features of low oestrogen.

- $\quad$ Serum estradiol $=20 \mathrm{pg} / \mathrm{ml}$

- $\quad$ Serum FSH and $\mathrm{LH}=>40 \mathrm{mIU} / \mathrm{ml}$.

All these points are applicable to menopause as well.

\section{Diagnostic approach to menopause vis-à-vis rajonivrutti:}

Menopause or Rajonivrutti should be considered as a physiological transformation in the life of a female individual. It is not a disease per se. Here doshas undergo Sanchaya-Prakopa-Prasara-Sthanasamshraya Avasthas, but do not undergo Vyakta Avastha in order to manifest as a Vyadhi.

Another point to be considered here is that there is Pitta pradhana Tridosha involvement with the lakshanas suggesting the disturbance of Sadhaka, Pachaka, Alochaka and Bhrajaka Pittas in the form of disturbed state of Buddhi-Medha, Arochaka-Asya Vairasya-Avipaka-Anaha-Kshudha Apravrutthi, blurring of vision-floaters and pallor-hot flushes respectively are seen. Hence rather than targeting with a single drug approach, it would be beneficial to include a holistic modality including physical, psychological and emotional statuses in order to combat this troublesome phase in female life.

\section{Conclusion:-}

A syndromic approach should be undertaken while treating geriatric patients, taking into account the consideration of the functional disabilities such as restriction of movement, diminution of vision, falls and so on, irrespective of the exact pathological causes. Maintenance of physical and psychological independence and reduction of the ill effects of age-related phenomena and diseases is one of the main goals of geriatric medicine.

It is primarily female group of elderly, many of whom live with chronic health problems, have low incomes. Caring refers to the physical, mental, and emotional activities and effort that are involved in looking after, responding to, 
and supporting others. In our society, the various forms of this work are done primarily by women throughout their lives. It is done as mothers, daughters, and wives in the context of individual relationships and in the community. It is high time we address their issues at the twilight stage of their life in order to improve the quality of their remaining life.The present study helps in drawing conclusions that menopause is a fairly manageable condition when Ayurvedic measures are followed and the accuracy of the Rajo Nivrutti Kala.

\section{References:-}

1. Das Krishna KV. Clinical Medicine: A Textbook of Clinical Methods and Laboratory Investigations. In, Thomas Matthew et.al(ed). Fourth edition 2013. Jaypee Brothers Medical Publishers (P) Ltd, New Delhi. p. 549.

2. Dutta D C. D C Dutta's Textbook of Gynaecology including contraception. In, Konar Hiralal(ed). Sixth edition 2013. New Central Book Agency (P) Ltd, New Delhi. p.56.

3. Guyton A C and Hall J E. Textbook of Medical Physiology. Eleventh edition 2008. Elsevier, a division of Reed Elsevier India Private Limited, New Delhi. p. 1022.

4. Acharya Sushrutha. Garbhaavakraanthim Shareeram. In, Vaidya Jadavji Trikamji Acharya(ed). Sushrutha Samhitha with Nibandha Sangraha commentary of Sri Dalhanacharya, Reprint edition of 2012. Varanasi, Chaukhamba Surbharati Prakashan: 2012. p. 351.

5. AcharyaVagbhata. Garbhaavakraanthim Shareeram. In, Pandit Hari Sadashiv Shastri Paradkar(ed). Ashtanga Hrudayam with Sarvanga Sundari commentary by Arunadutta and Ayurveda Rasayana commentary by Hemadri, Reprint edition of 2015. Varanasi, Chaukhamba Sanskrutha Sansthana: 2015. p. 363.

6. Sharangadhara samhita, edited by Bramhananda tripathi, Chaukambha surabharati prakashana, reprint 2006, purvakhanda $7^{\text {th }}$ chapter. p. 30 .

7. Acharya Agnivesha. Garbhavakranti Shareeram 4/34. In, Vaidya Yadavji Trikamji Acharya(ed). Charaka Samhitha revised by Acharya Charaka and Dridhbala with Ayurvedadipika commentary by Sri Chakrapanidatta, Reprint edition 2011. Varanasi: Chaukhamba Surbharati Prakashan; 2011. p. 323. 